Transactions, SMiRT-25

Charlotte, NC, USA, August 4-9, 2019

Division II

\title{
European project ATLAS+: Small and large scale ductile tearing experiments on ferritic steel WB36 to study transferability of material ductile properties
}

\author{
Dominique Moinereau ${ }^{1}$, Patrick Le Delliou ${ }^{2}$, Anna Dahl ${ }^{3}$, Willy Vincent ${ }^{4}$ \\ ${ }^{1}$ EDF R\&D, Les Renardières, France (dominique.moinereau@edf.fr) \\ ${ }^{2}$ EDF R\&D, Les Renardières, France \\ ${ }^{3}$ EDF R\&D, Les Renardières, France \\ ${ }^{4}$ EDF R\&D, Les Renardières, France
}

\begin{abstract}
The 4-years European project ATLAS+ (Advanced Structural Integrity Assessment Tools for Safe long Term Operation) has been launched in June 2017. One of its objectives is to study the transferability of material ductile properties from small scale specimens to large scale components and validate some advanced tools for structural integrity assessment. The study of properties transferability is based on a wide experimental programme which includes a full set of fracture experiments conducted on conventional fracture specimens and large scale components (mainly pipes). Three materials are considered in the programme : a ferritic steel WB36 typical from secondary feedwater line in German PWR reactors, an aged stainless steel austenitic weld representative from EPR design and a typical VVER austenitic dissimilar weld (DMW).

This paper describes the experimental work conducted on the ferritic steel WB 36 and summarizes the experimental results available after 2 years of work. Numerous mechanical tests have been conducted on a wide panel of fracture mechanics specimens for a full characterization of the ferritic steel: Tensile properties, Hardness, Charpy Energy, pre-cracked Charpy PCC, Master curve on CT and SENT specimens, ductile tearing properties on CT and SENT specimens ...

In parallel, it is planned to conduct three 4PB large scale tests on pipings (FP1, FP2 and FP3) at room temperature on the EDF test facility with 3 configurations (shape, size and location) of cracks : through wall crack (TWC), internal and external $1 / 2$ elliptical cracks. Progress of these large scale experiments is described including first results.
\end{abstract}

\section{INTRODUCTION}

ATLAS + project has been launched in 2017 [1]. The corresponding organization is summarized on Figure 1. Work-package 1 (WP 1) is dedicated to the design and execution of innovative, simulation oriented, large scale experiments on different mock-ups [2]. These experiments are dedicated to investigating the transferability of material properties from small laboratory specimens to practical full scale components. Of particular interest are the different constraint conditions in laboratory specimens and large scale tests. The results of these tests will be used for validation of the advanced tools developed in work-package 3 (WP 3).

WP 1 includes three major tasks, conducted in 3 sub work-packages:

- the design of large scale experiments, based on 3D finite elements analyses, to verify the experiments feasibility and define the most appropriate experimental conditions (WP 1.1) [3][4]

- the materials characterization and the large scale experiments (WP 1.2) [5][6] 
- the final fractographic examinations of fracture surfaces, including some benchmarks between laboratories (WP 1.3)

Three representative materials are considered in the project:

- the ferritic steel 15NiCuMoNb5 (WB 36) representative of German PWR secondary feedwater lines

- the aged austenitic stainless steel aged weld representative of EPR design (narrow gap)

- a dissimilar weld representative of VVER plant

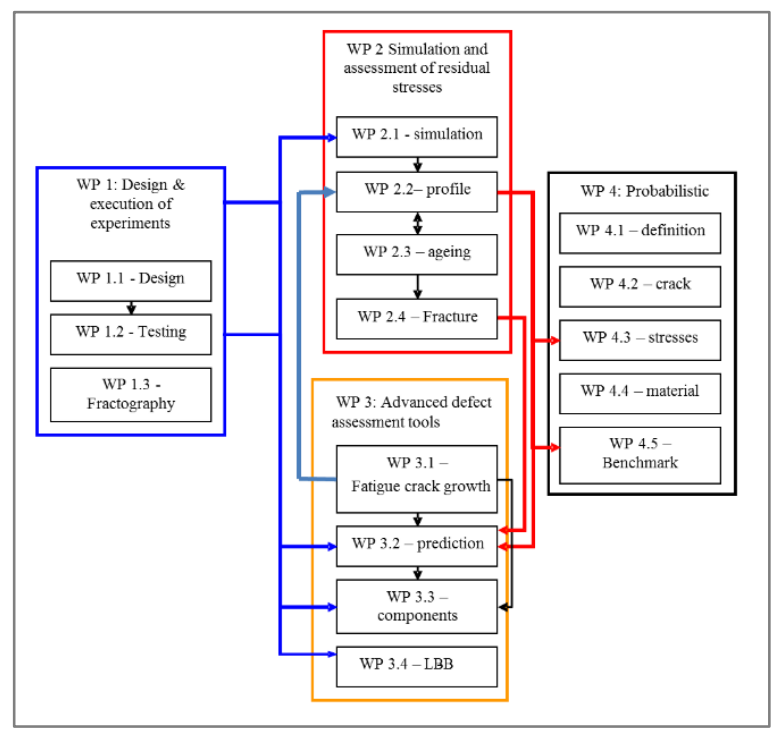

Figure 1. ATLAS+ technical work-packages

This paper summarizes the experimental work conducted on the ferritic steel $15 \mathrm{NiCuMoNb} 5$ (WB36) by the partners of the project.

\section{EXPERIMENTAL CHARACTERIZATION OF THE FERRITIC STEEL 15NiCuMoNb5}

Several organizations are involved in the characterization of the ferritic steel, summarized in Table 1 . This characterization includes tests on both standard fracture mechanics specimens (Table 2) and three large scale experiments on cracked pipes.

Table 1: Contributions to material characterization of the ferritic steel $15 \mathrm{NiCuMoNb} 5$

\begin{tabular}{|c|c|c|c|}
\hline Material & $\begin{array}{c}\text { Materials } \\
\text { characterization }\end{array}$ & $\begin{array}{c}\text { Design of } \\
\text { experiments }\end{array}$ & $\begin{array}{c}\text { Large } \\
\text { scale tests }\end{array}$ \\
\hline & EDF & & \\
& KIWA Inspecta & & \\
Ferritic steel & VTT & Framatome GmbH & \\
$15 \mathrm{NiCuMoNb5}$ & BTAN & EDF & EDF \\
& ARMINES & KIWA Inspecta & \\
& CIEMAT & VTT & \\
& Framatome GmbH & & \\
& CEA & & \\
\end{tabular}


Table 2: Programme of material characterization of the ferritic steel $15 \mathrm{NiCuMoNb} 5$

\begin{tabular}{|c|c|c|c|c|c|}
\hline Properties & Specimens & Orientation & Partners & Available & To do \\
\hline Chemistry & & & EDF & $x$ & \\
\hline Tensile & $\begin{array}{l}\text { TC5 } \\
\text { TC6 }\end{array}$ & L & $\begin{array}{c}\text { KIWA } \\
\text { EDF, BZN }\end{array}$ & $x$ & \\
\hline Charpy & KCV & $\begin{array}{l}\text { LT } \\
\text { LS }\end{array}$ & EDF, MTA EK & $\begin{array}{l}x \\
x\end{array}$ & \\
\hline Master curve & $\begin{array}{l}\text { CTJ10 } \\
\text { CTJ12.5 } \\
\text { SENT } \\
\text { CT5 }\end{array}$ & $\begin{array}{c}\text { LS } \\
\text { LT } \\
\text { LS } \\
\text { TS, ST, TL }\end{array}$ & $\begin{array}{l}\text { BZN } \\
\text { EDF } \\
\text { VTT } \\
\text { CIEMAT }\end{array}$ & $\begin{array}{l}x \\
x \\
x \\
x\end{array}$ & $x$ \\
\hline $\begin{array}{l}\text { Notched } \\
\text { tensile NT }\end{array}$ & $\begin{array}{c}\text { AE2 } \\
\text { AE4 } \\
\text { AE10 }\end{array}$ & L & $\begin{array}{c}\text { EDF } \\
\text { CEA } \\
\text { ARMINES }\end{array}$ & $\begin{array}{l}x \\
x \\
x\end{array}$ & \\
\hline $\begin{array}{l}\text { Pre-cracked } \\
\text { Charpy PCC }\end{array}$ & PCC & LS & MTA EK & No & \\
\hline$J-\Delta a$ & CTJ20 & LT & $\begin{array}{c}\text { KIWA } \\
\text { EDF } \\
\text { ARMINES }\end{array}$ & $\begin{array}{l}x \\
x \\
x\end{array}$ & \\
\hline$J-\Delta a$ & SENT & LT & $\begin{array}{c}\text { EDF } \\
\text { ARMINES }\end{array}$ & $\begin{array}{l}x \\
x\end{array}$ & \\
\hline Shear & $\begin{array}{l}\text { Iosipescu } \\
\text { 'Smiley' }\end{array}$ & L & $\begin{array}{l}\text { KIWA } \\
\text { CEA }\end{array}$ & $x$ & $x$ \\
\hline Hardness & $\mathrm{Hv}$ & & CIEMAT & $x$ & \\
\hline Microstructure & SEM & NT, SENT & CIEMAT & $x$ & \\
\hline Tomography & & & ARMINES & $x$ & $x$ \\
\hline $\begin{array}{c}\text { Small } \\
\text { specimens }\end{array}$ & $\begin{array}{l}\text { Tensile } \\
\text { CT10 }\end{array}$ & $\stackrel{\text { L }}{\text { LT, LS }}$ & Framatome $\mathrm{GmbH}$ & $\begin{array}{l}x \\
x\end{array}$ & \\
\hline
\end{tabular}

A comprehensive metallurgical and mechanical characterization is included, based on a full set of standard fracture mechanics specimens (Chemistry, tensile and Charpy properties, brittle fracture toughness $\mathrm{K}_{\mathrm{Jc}}$, ductile tearing J- $\Delta \mathrm{a}$, notched tensile specimens, etc.). Some innovative in-situ mechanical tests on sub-sized specimens (CT, SENT, etc.) are also conducted at Saclay SOLEIL synchrotron with X-ray tomography for a better knowledge of fracture process. These mock-ups further addresses transferability issues from laboratory size specimen to a reduced size mock-up. To accomplish this task, small scale experiments are made to complement available material data. In particular, SENT experiments are performed to obtain fracture mechanics data.

\section{LOCATION OF SPECIMENS}

Numerous specimens are used and tested for the characterization of the ferritic steel $15 \mathrm{NiCuMoNb} 5$, extracted from a ferritic pipe provided by Framatome $\mathrm{GmbH}$ (Figures 2 and 3, including the location of specimens along the circumference and through the thickness of the pipe). The thickness of the pipe is 30 $\mathrm{mm}$. Homogeneity of the material is also examined, with specimens through the wall thickness or along the pipe circumference.
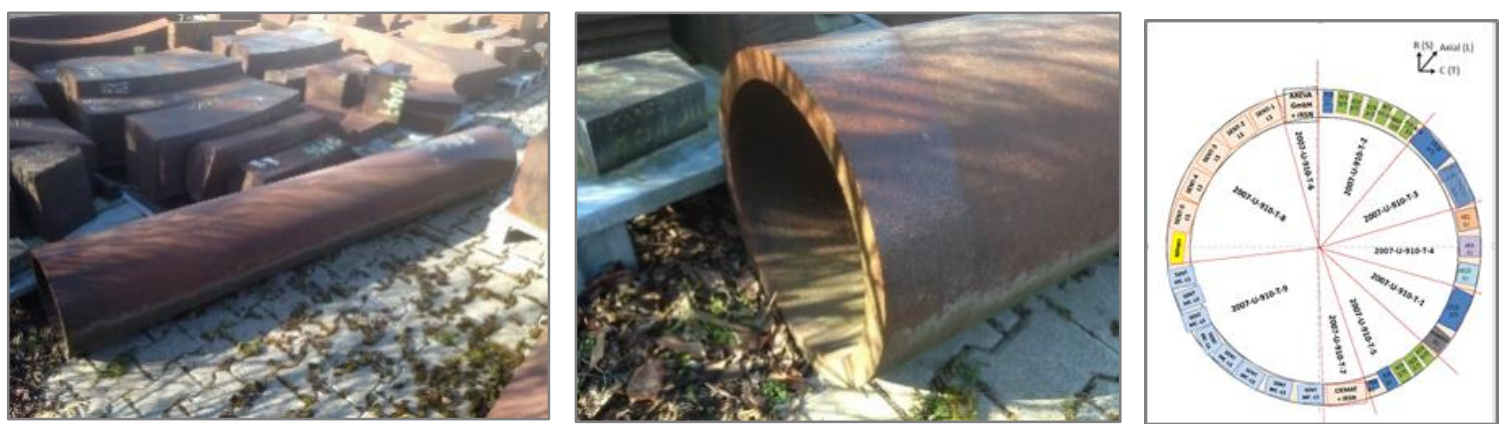

Figure 2. Original ferritic pipe provided by Framatome $\mathrm{GmbH}$ and location of specimens for material characterization 

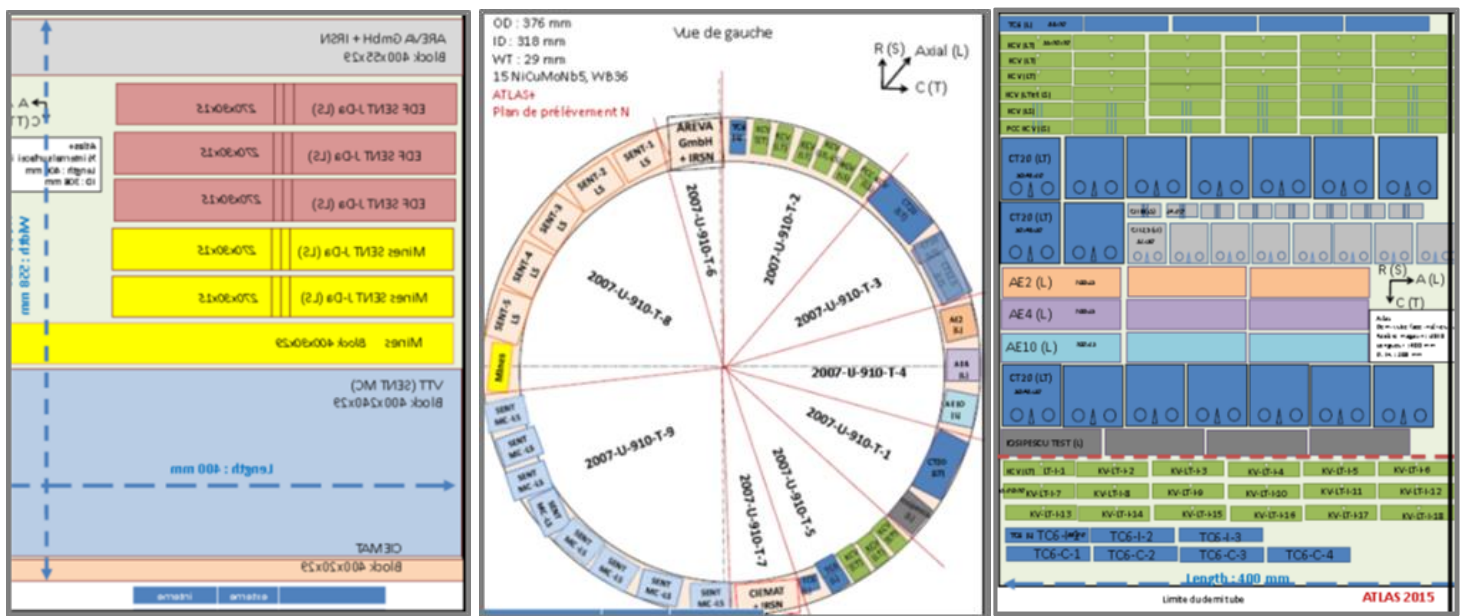

Figure 3. Location of specimens in ferritic pipe $15 \mathrm{NiCuMoNb5}$

\section{CHEMICAL COMPOSITION}

The chemical analyses of the $15 \mathrm{NiCuMoNb} 5$ ferritic steel made by EDF are presented in Table 3 and compared to previous data from Framatome $\mathrm{GmbH}$ obtained on similar materials (but produced from different heats). Some small differences can be noticed between the difference heats, mainly on $\mathrm{Si}, \mathrm{S}, \mathrm{Cr}$, $\mathrm{Al}$ and $\mathrm{Sn}$.

Table 3: Chemical analyses of the $15 \mathrm{NiCuMoNb} 5$ ferritic steel. Comparison with previous Framatome $\mathrm{GmbH}$ data obtained on similar materials

\begin{tabular}{|c|c|c|c|c|c|c|c|c|c|c|c|c|c|c|c|c|c|}
\hline & c & Si & $\mathrm{Mn}$ & $\mathbf{P}$ & 5 & $\mathrm{cr}$ & Mo & $\mathrm{Ni}$ & Al & Sn & $\mathrm{Cu}$ & As & $N$ & $\mathrm{Nb}$ & $\mathrm{v}$ & $\mathrm{Nb}$ & 0 \\
\hline EDF & 0,1400 & 0,3100 & 0,9400 & 0,0090 & 0,0200 & 0,4000 & 0,3500 & 1,1400 & 0,0150 & 0,0130 & 0,6200 & & 0,0130 & & & 0,0300 & 0,0030 \\
\hline $\begin{array}{c}\text { AREVA } \\
\text { GmbH } 1 \\
38 \mathrm{~mm}\end{array}$ & 0,1400 & 0,4000 & 0,9300 & 0,0080 & 0,0100 & 0,2200 & 0,3600 & 1,1500 & 0,0280 & 0,0050 & 0,6100 & 0,0080 & 0,0125 & 0,0230 & 0,0060 & & \\
\hline $\begin{array}{l}\text { AREVA } \\
\text { GmbH } 2 \\
35 \mathrm{~mm}\end{array}$ & 0,1500 & 0,3400 & 1,0000 & 0,0100 & 0,0140 & 0,2000 & 0,3400 & 1,1700 & 0,0260 & 0,0100 & 0,6000 & 0,0110 & 0,0123 & 0,0240 & & & \\
\hline $\begin{array}{l}\text { AREVA } \\
\text { GmbH } 3 \\
65 \mathrm{~mm}\end{array}$ & 0,1500 & 0,4000 & 1,0700 & 0,0090 & 0,0080 & 0,2200 & 0,3600 & 1,1700 & 0,0320 & & 0,6100 & & 0,0105 & & & & \\
\hline
\end{tabular}

\section{TENSILE PROPERTIES}

The tensile properties have been measured using TC6 and TC5 specimens at room temperature by several partners at different locations, along the circumference of the pipe and through the wall thickness. A synthesis of these properties is given on Figure 4.
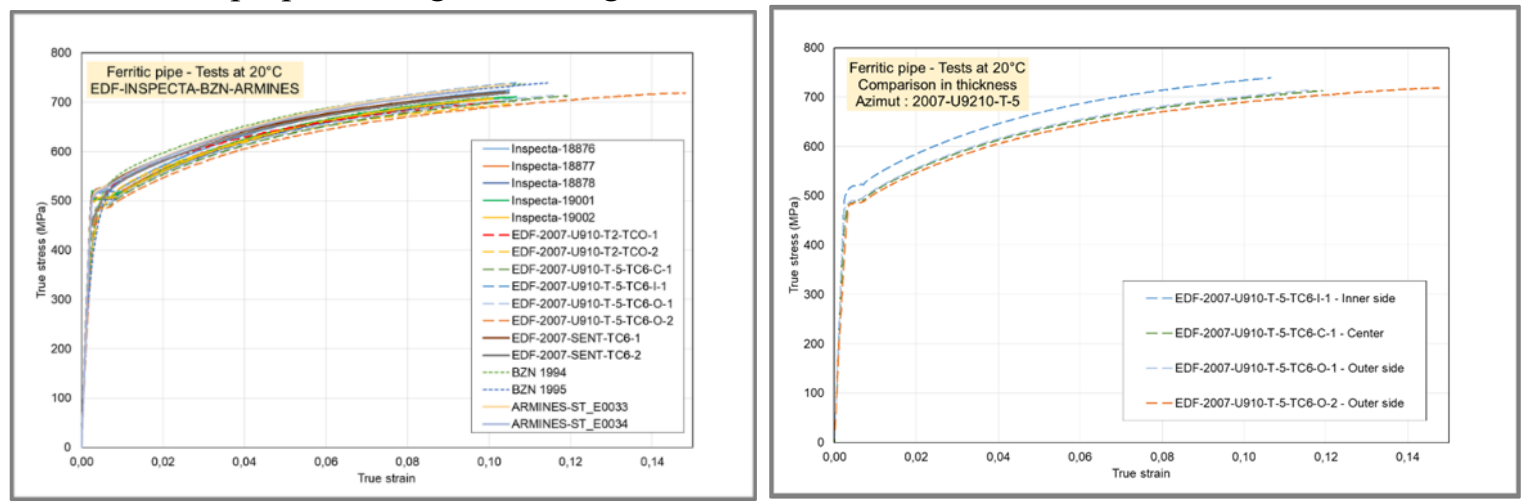

Figure 4. Synthesis of the tensile properties of the ferritic steel 15NiCuMoNb5 (room temperature) 
These figures show a clear inhomogeneity of the tensile properties, depending on the location of the TC tensile specimens along the circumference or through the thickness of the pipe. In some cases, the Luders plateau is not observed.

\section{TESTS ON CHARPY SPECIMENS}

Tests on Charpy KCV specimens, made by 2 partners with specimens located with different locations and orientations (LT or LS) are summarized on Figure 5. The results show a large scatter of Charpy energy (resilience in $\mathrm{daJ} / \mathrm{cm}^{2}$ ) whatever the experimental conditions (orientation LT or LS, location through the pipe thickness or along the pipe circumference).
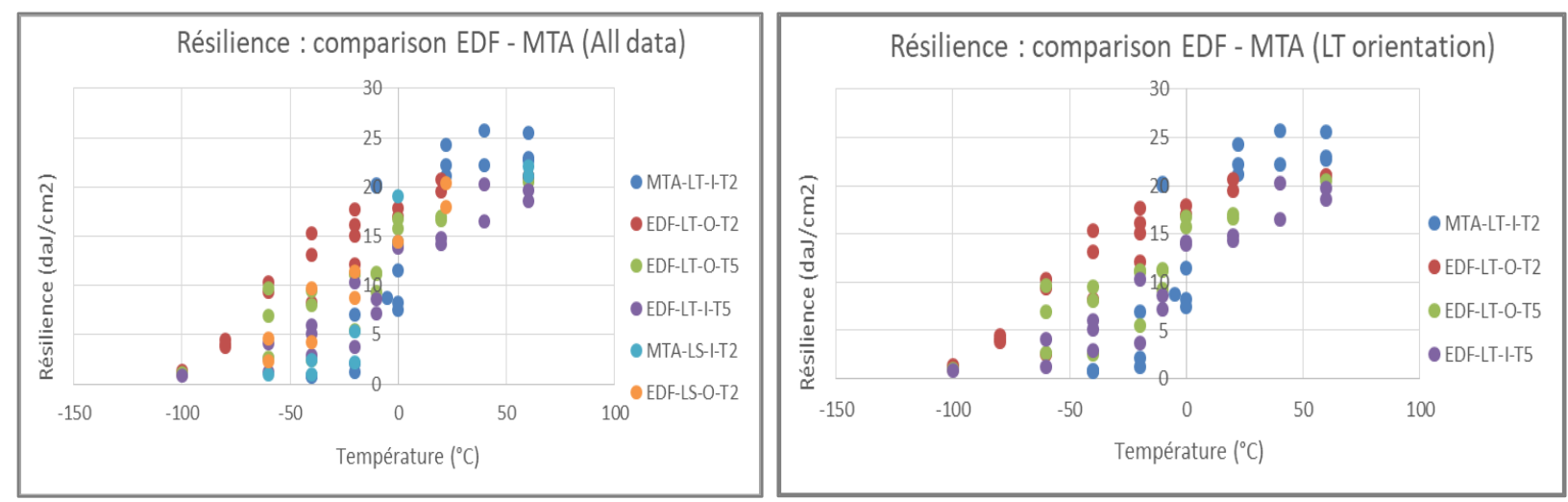

Figure 5: Experimental results on all Charpy KCV specimens (all data and LT orientation)

\section{MASTER CURVE: DETERMINATION OF T}

Based on the Master curve approach, the brittle fracture toughness properties of the ferritic steel have been determined by different partners, using different kinds and geometries of specimens (CT or SENT, Table 4). All the specimens failed by cleavage. Table 5 gives an evaluation of the transition temperature $\mathrm{T}_{0}$ obtained on each set of specimens. We can notice a very low transition temperature on the different sets of data. Figures 6 gives an illustration on the Master curves obtained on CTJ12.5 (EDF) and SENT (VTT). Figure 7 shows an illustration of the brittle fracture obtained on the CTJ specimens.

Table 4: Brittle fracture toughness programme (determination of $\mathrm{T}_{0}$ )

\begin{tabular}{|c|c|c|c|c|c|}
\hline Partner & Block & Specimen & Side grooved & $a_{0} / \mathrm{W}$ & Orientation \\
\hline EDF & $2007-$ U-910-T-3 & 8 CTJ12.5 & $10 \%$ & $0.45<\mathrm{a}_{0} / \mathrm{W}<0.55$ & LT \\
\hline BZN & $2007-$ U-910-T-3 & 7 CTJ10 & $10 \%$ & $0.45<\mathrm{a}_{0} / \mathrm{W}<0.55$ & LS \\
\hline VTT & $2007-$ U-910-T-9 & 8 SENT $(20 \star 20 \mathrm{~mm})$ & $15 \%$ & $\sim 0.53-0.54$ & LT \\
\hline CIEMAT & $2007-$ U-910-T-7 & CT5 & No & $\sim 0.5$ & TS, ST, TL \\
\hline
\end{tabular}

Table 5: Synthesis of brittle fracture tests on CT and SENT specimens. $\mathrm{T}_{0}$ evaluation

\begin{tabular}{|c|c|c|c|c|c|c|}
\hline Partner & Block & Validated specimen & Side grooved & ao/W & Orientation & $\mathrm{T}_{0}\left({ }^{\circ} \mathrm{C}\right)$ \\
\hline EDF & $2007-\mathrm{U}-910-\mathrm{T}-3$ & 8 CTJ12.5 & $20 \%$ & $\sim 0.5$ & LT & -99 \\
\hline BZN & $2007-U-910-T-3$ & 7 CTJ10 & $20 \%$ & $\sim 0.5$ & LS & -116 \\
\hline VTT & $2007-U-910-T-9$ & 7 SENT $(20 * 20 \mathrm{~mm})$ & $15 \%$ & $\sim 0.53-0.54$ & LT & -101 \\
\hline & & & & & TS & -102 \\
CIEMAT & $200-U-910-T 7$ & 14 CT5 & \multirow{2}{*}{ No } & $\sim 0.5$ & ST & -74 \\
& & & & & TL & -94 \\
& & & & & All specimens & -92 \\
\hline
\end{tabular}



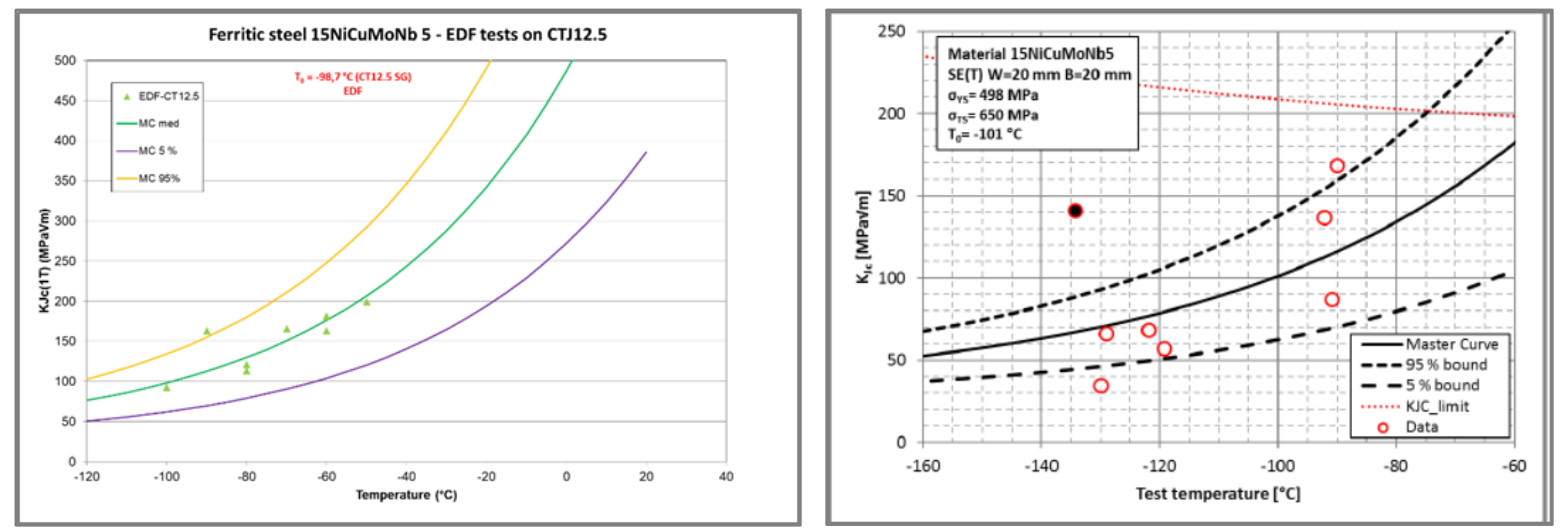

Figure 6. Experimental fracture toughness results on CTJ12.5 (EDF) and SENT specimens (VTT)
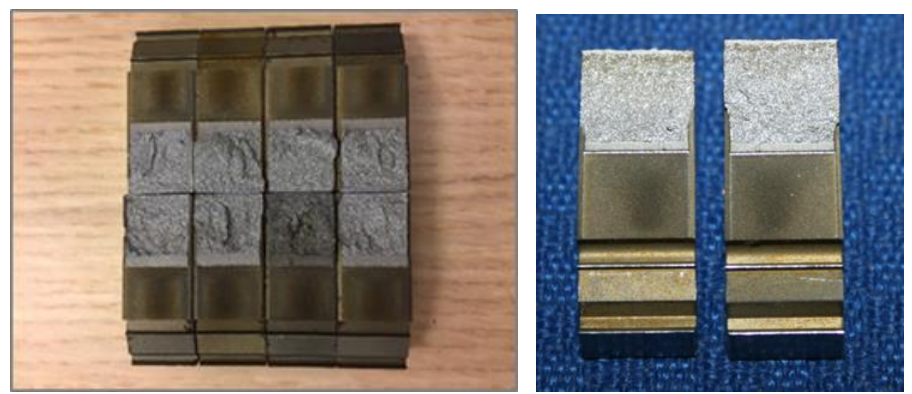

Figure 7. Brittle fracture tests on CTJ12.5 (EDF, left) and CTJ10 (BZN, right) specimens

\section{TESTS ON NOTCHED TENSILE SPECIMENS}

In order to calibrate some numerical damage models, tests have been performed by three organizations at room temperature with three notch radii $(2 \mathrm{~mm}, 4 \mathrm{~mm}$ and $10 \mathrm{~mm}$, specimens AE2, AE4 and AE10)(Figure $8)$. For this geometry, the smaller the notch radius is, the higher the triaxiality is.

Main results are presented on Figure 8 (Load versus Diametral contraction). The agreement between the partners is excellent on all specimens (AE2, AE4 and AE10). The effect of the triaxiality is clear on the maximum load and diametral contraction (comparison between AE2, AE4 and AE10 specimens). The fractographic analyses of the fracture surfaces confirm a ductile tearing mode of fracture on all specimens.
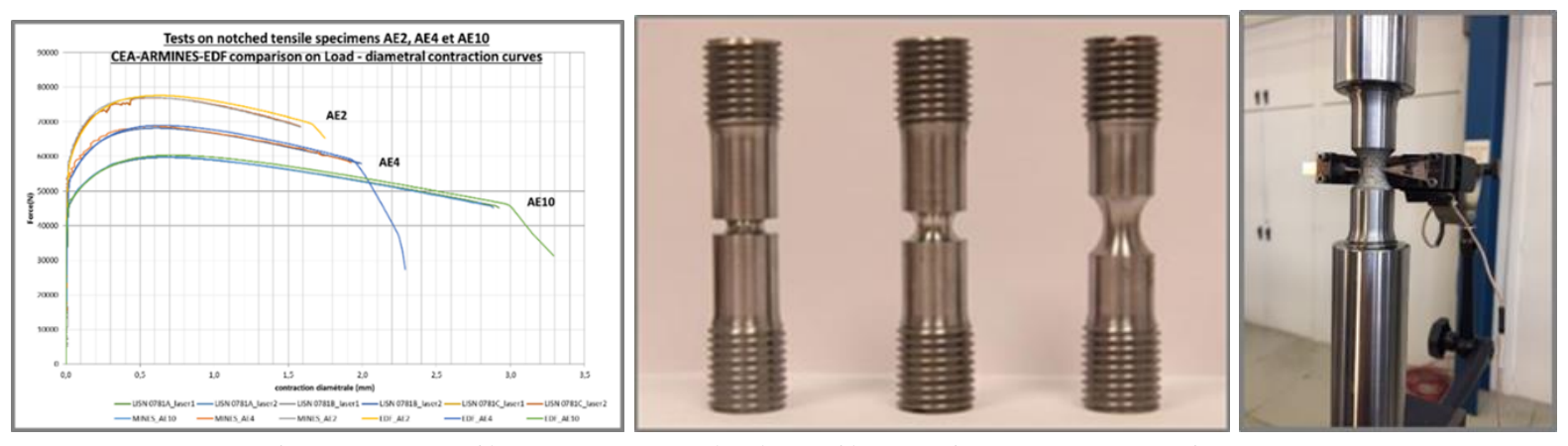

Figure 8. Tensile tests on notched tensile specimens (NT specimens)

\section{DUCTILE TEARING TESTS}

Ductile tearing tests were performed at room temperature on several specimen geometries (Table 6):

- CTJ20: CT specimens with thickness $B=20 \mathrm{~mm}$ and $\mathrm{a} / \mathrm{W}=0.5$ or $\mathrm{a} / \mathrm{W}=0.6$ 
- CTJ10: CT specimens with thickness $B=10 \mathrm{~mm}$ and $\mathrm{a} / \mathrm{W}=0.6$

- SENT specimens: Single edged notched tensile specimen (Figure 9) with thickness B=30mm and $\mathrm{a} / \mathrm{W}=0.5$

- all specimens are side grooved

An illustration of some of the experimental results is given on Figures 10 (Load vs COD on CTJ specimens) and 11 (Load vs COD on SENT specimens). The main observations of these tests can be summarized as follow:

- all the specimens failed by ductile tearing except 3 CTJ20 specimens (tested by EDF)

- these three EDF CTJ20 specimens failed by cleavage after a certain amount of ductile tearing

- a good agreement between the CTJ specimens is observed on the experimental Load vs COD curves if the specimens are similar (more particularly a/W)

- a very good agreement between the SENT specimens on the Load vs COD curves

Table 6: Experimental ductile tearing tests programme on CT and SENT specimens

\begin{tabular}{|c|c|c|c|c|c|c|}
\hline Partner & Block & Specimens & Temperature & Side grooved & $\mathrm{a}_{0} / \mathrm{W}$ & Orientation \\
\hline EDF & $\begin{array}{l}2007-U-910-T-3 \\
2007-U-910-T 8\end{array}$ & $\begin{array}{l}9 \text { CTJ20 } \\
3 \text { SENT }\end{array}$ & \multirow{4}{*}{$20^{\circ} \mathrm{C}$} & $\begin{array}{l}\text { Yes }\left(B_{N}=16 \mathrm{~mm}\right) \\
\text { Yes }\left(B_{N}=27 \mathrm{~mm}\right)\end{array}$ & $\begin{array}{l}\sim 0.6 \\
\sim 0.5\end{array}$ & $\begin{array}{l}\text { LT } \\
\text { LS }\end{array}$ \\
\hline ARMINES & $\begin{array}{l}2007-U-910-T-3 \\
2007-U-910-T-8\end{array}$ & $\begin{array}{l}2 \text { CTJ20 } \\
2 \text { SENT }\end{array}$ & & $\begin{array}{l}\text { Yes }\left(B_{N}=16 \mathrm{~mm}\right) \\
\text { Yes }\left(B_{N}=27 \mathrm{~mm}\right)\end{array}$ & $\begin{array}{l}\sim 0.6 \\
\sim 0.5\end{array}$ & $\begin{array}{l}\text { LT } \\
\text { LS }\end{array}$ \\
\hline KIWA & 2007-U-910-T-1 & 4 CTJ20 & & $\begin{array}{l}\text { Yes }\left(B_{N}=18 \mathrm{~mm}\right) \\
\text { Yes }\left(B_{N}=16 \mathrm{~mm}\right) \\
\text { Yes }\left(B_{N}=16 \mathrm{~mm}\right) \\
\text { Yes }\left(B_{N}=16 \mathrm{~mm}\right)\end{array}$ & $\begin{array}{l}\sim 0.5 \\
\sim 0.5 \\
\sim 0.5 \\
\sim 0.6\end{array}$ & LT \\
\hline Framatome $\mathrm{GmbH}$ & 2007-U-910-T-6 & 4 CT10 & & $\begin{array}{c}\text { Yes }(20 \%) \\
B_{N}=8 \mathrm{~mm}\end{array}$ & $\sim 0.6$ & $\begin{array}{l}\text { LT (O) } \\
\text { LT (O) } \\
\text { LT (S) } \\
\text { LS (C) }\end{array}$ \\
\hline
\end{tabular}

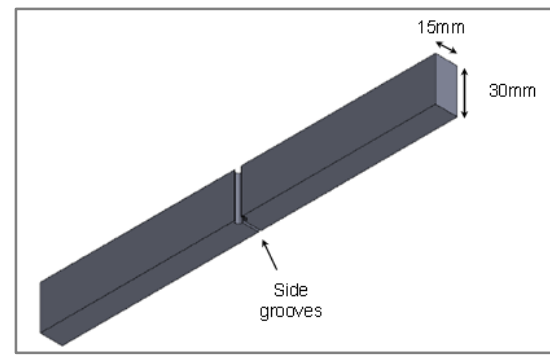

Figure 9. Drawing of SENT specimens
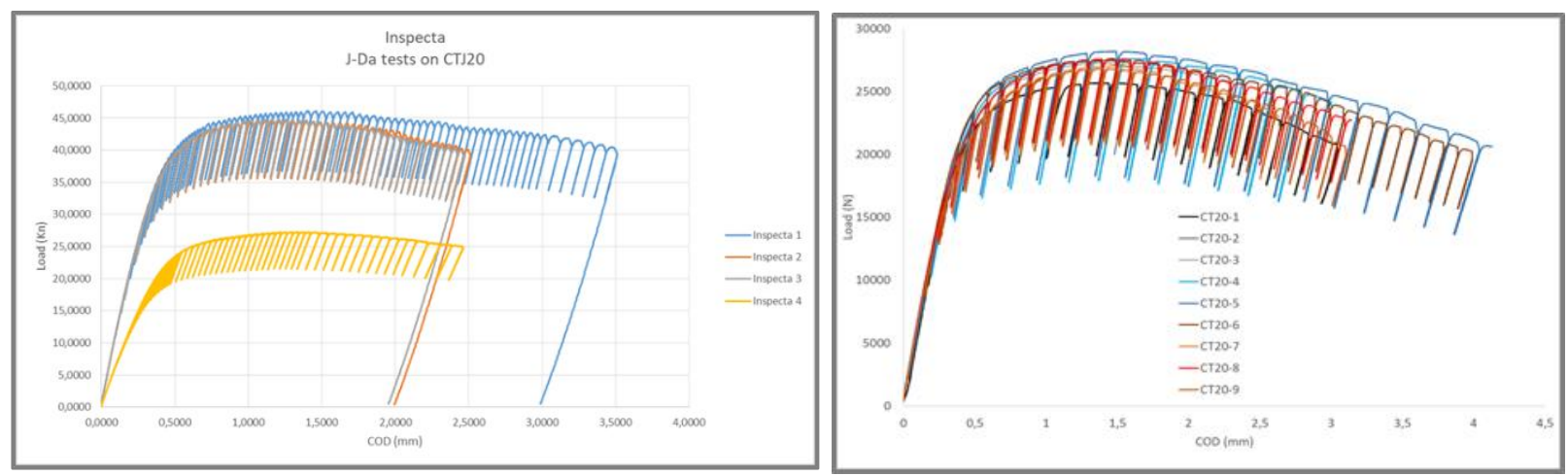

Figure 10. Inspecta (left) and EDF ARMINES (right) ductile tearing tests on CTJ20 (Load vs COD) 


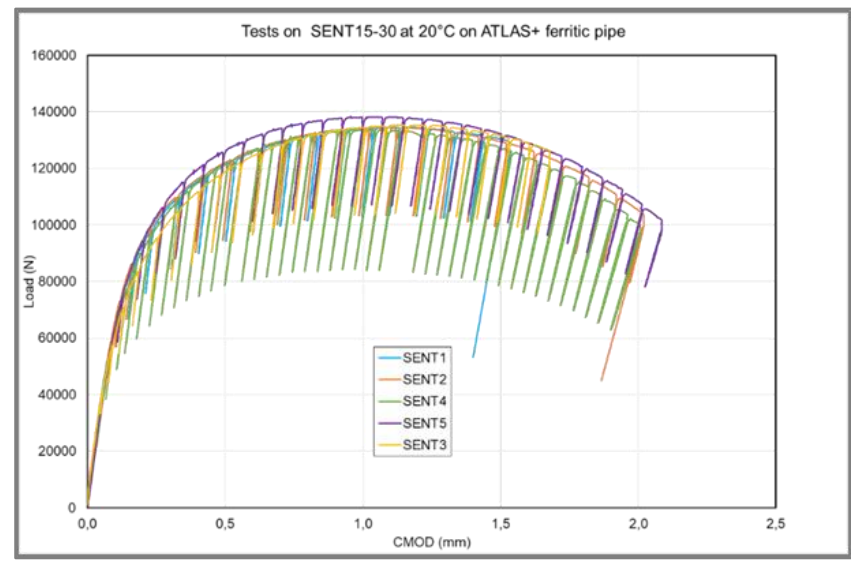

Figure 11. EDF and ARMINES ductile tearing tests on SENT specimens (Load vs COD)

An illustration of fracture surfaces after the tests is given on Figures 12 (CTJ specimens) and 13 (SENT specimens).
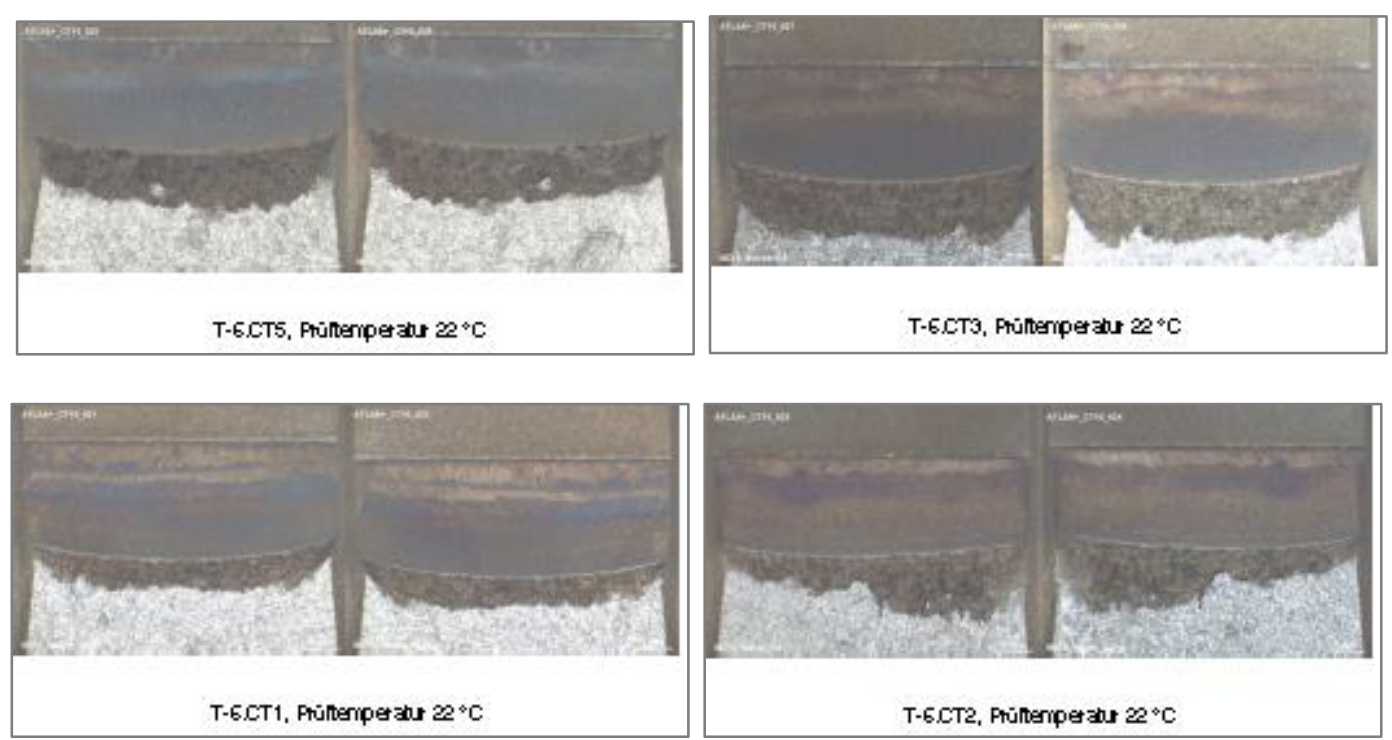

Figure 12. Fracture surfaces observed on CTJ10 specimens
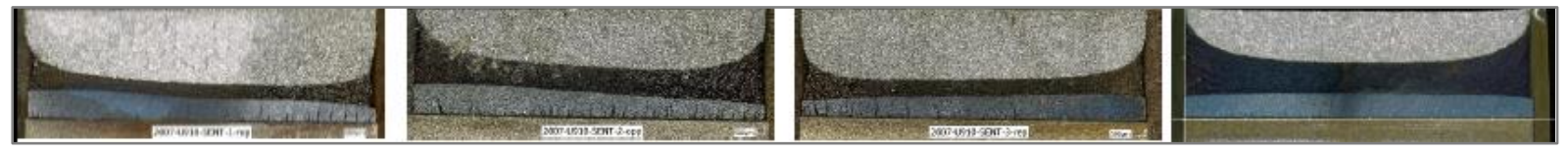

Figure 13. Fracture surfaces observed on SENT specimens

The determination of the J-R curves has been made for the tests according ASTM E1820 standard. Some illustrations are given for the CTJ specimens on Figures 14 (CTJ10 and CTJ20 specimens) and 15 (all specimens). J-R curves deduced from the SENT specimens are given on Figure 16.

Figure 17 gathers the J-R curves obtained on all the specimens (CTJ and SENT specimens). We notice a significant effect of specimen geometry (CTJ versus SENT specimens) on the ductile tearing resistance, the SENT specimens showing a higher resistance on ductile crack growth due to constraint (black curves). There is no effect on ductile initiation. 

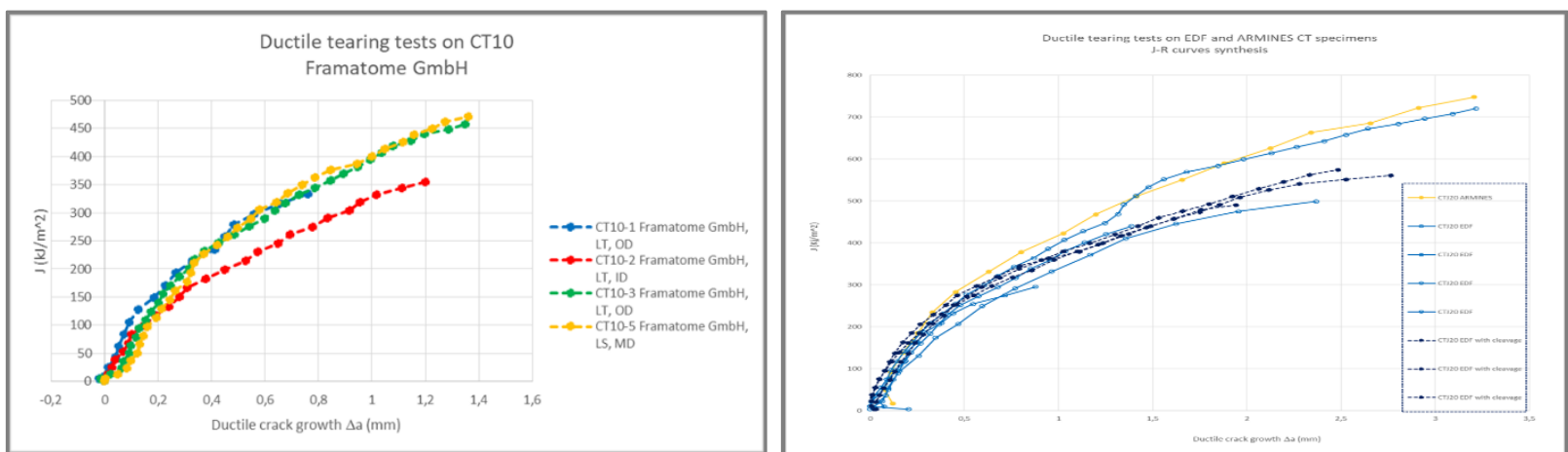

Figure 14. J-R curves obtained on CTJ10 (left) and CTJ20 (right) specimens

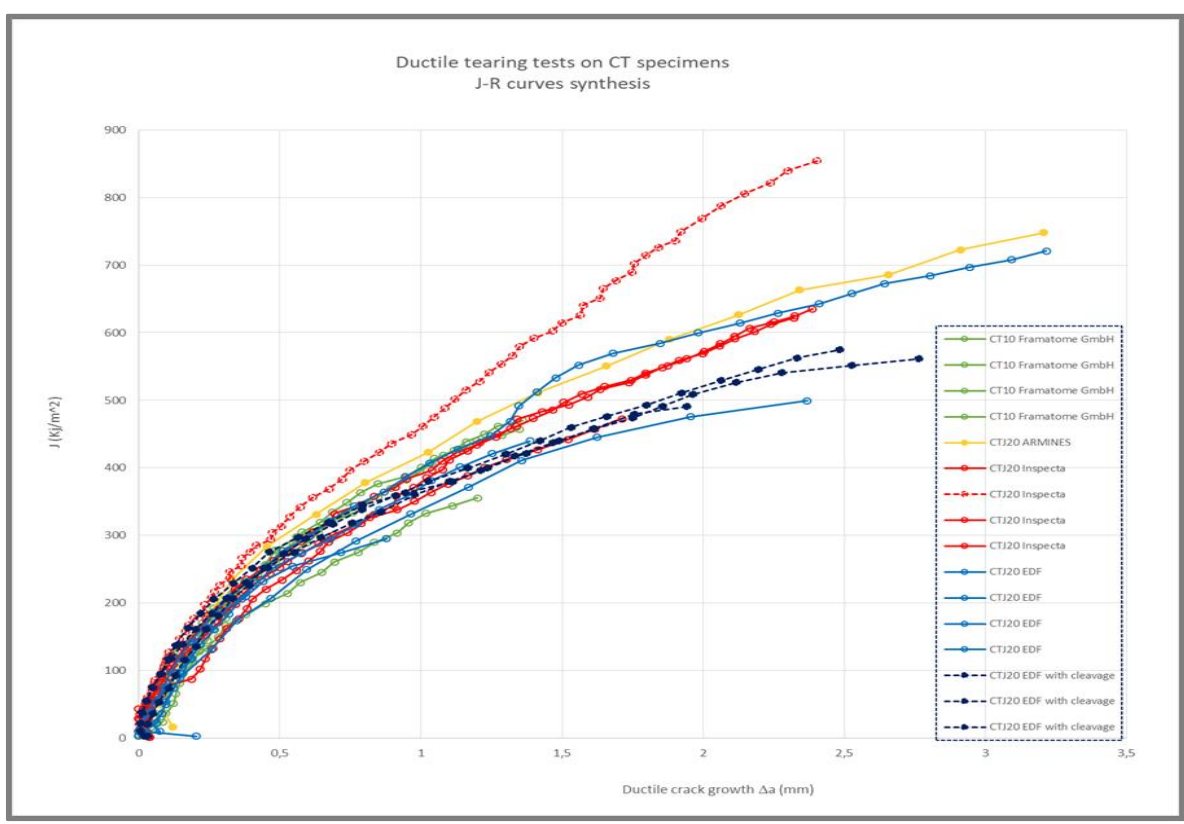

Figure 15. J-R curves obtained on all CTJ specimens

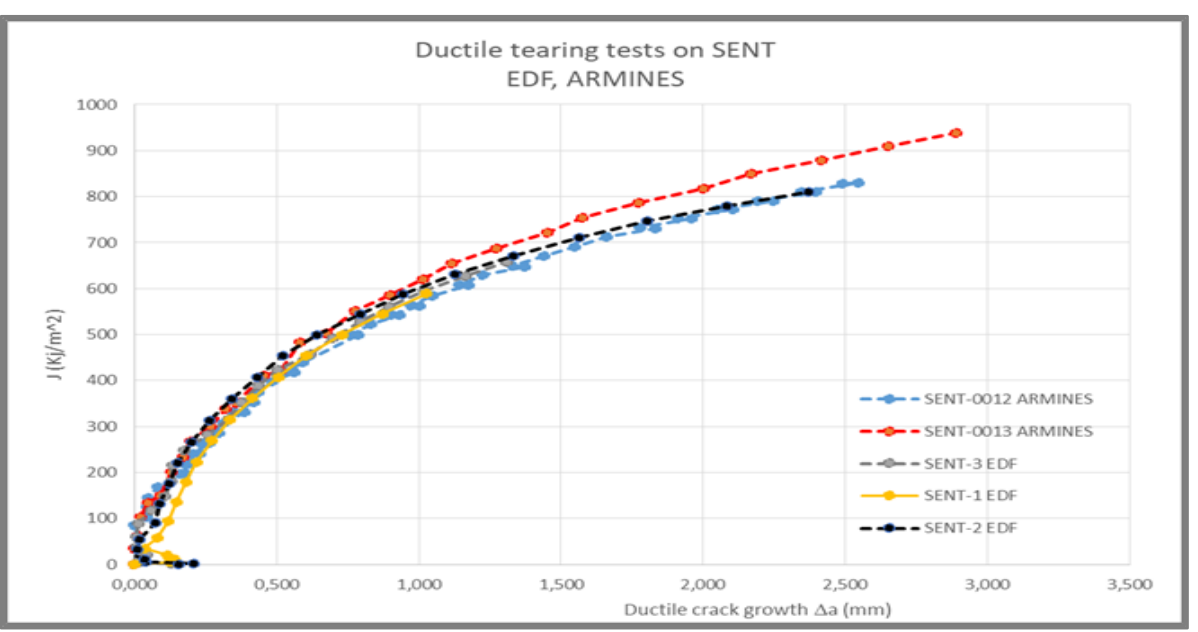

Figure 16. J-R curves obtained on SENT specimens 


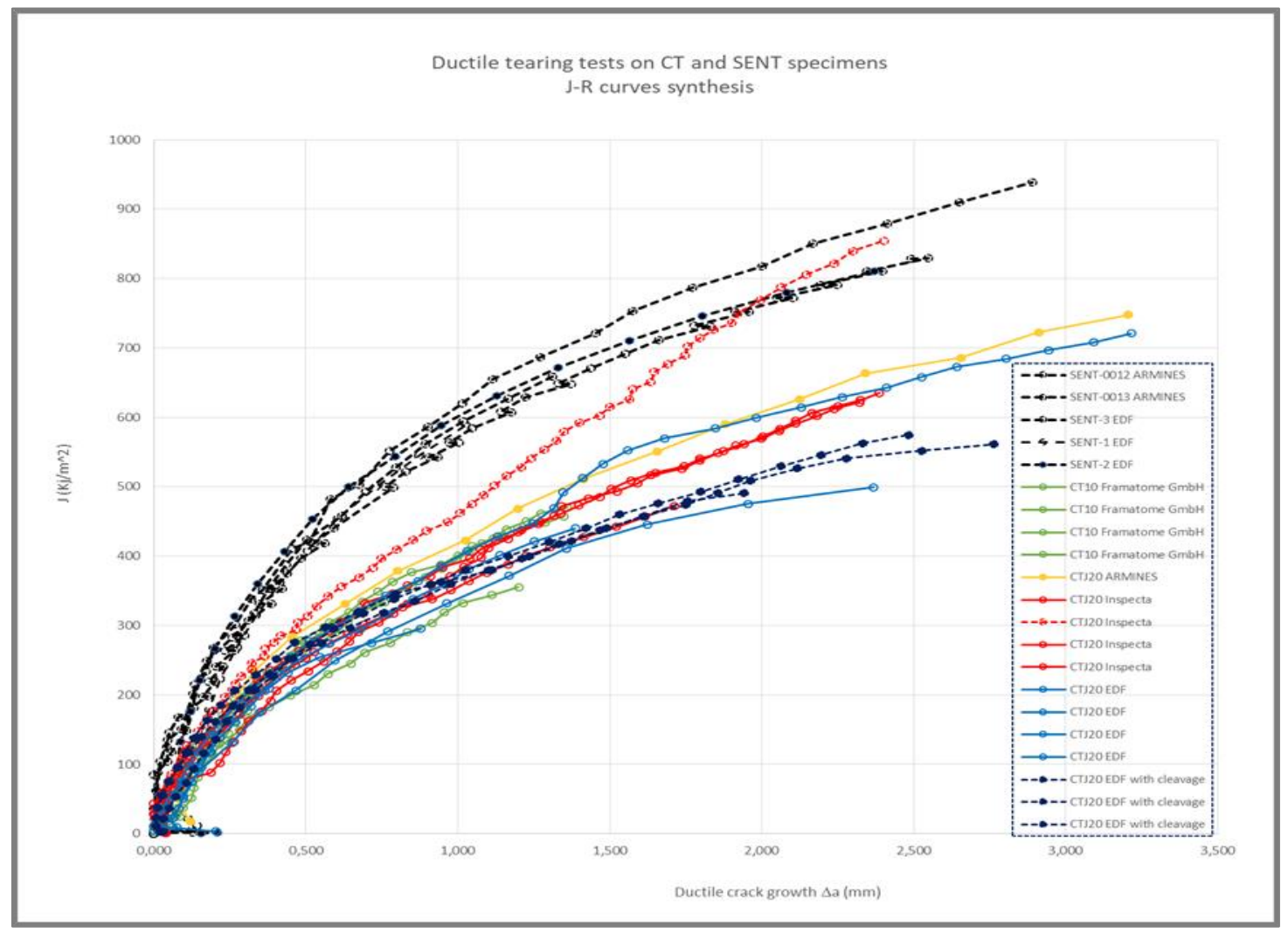

Figure 17. J-R curves obtained on all specimens (CTJ and SENT)

\section{OTHER PROPERTIES}

Other properties are available but not mentionned in this paper:

- HV10 Hardness measurements

- Microstructural observations of specimens (SEM, EBSD)

- Shear tests at room temperature on specific specimens (modified Iosipescu specimens)

- Some tomography tests are in progress on in-situ small specimens (NT and SENT) in Saclay SOLEIL synchroton

\section{LARGE SCALE EXPERIMENTS ON FERRITIC PIPES}

Three large scale experiments FP1, FP2 and FP3 are planned by EDF at room temperature on mock-ups consisting of ferritic pipes submitted to a four-point bending loading on the EDF test facility developed during former STYLE project [6]. The objectives of the tests are to obtain a significant ductile tearing growth in radial and (or) circumferential directions. More details about this programme are available in paper [2]. The central part of each mock-up is taken from the original $15 \mathrm{NiCuMoNb} 5$ ferritic steel pipe provided by Framatome GmbH (also used for this material characterization), and then welded to two E355 steel bending arms. Some design analyses have been previously performed in order to define the best experimental conditions [3][4]. Table 7 and Figure 18 show the test facility and the initial flaw shapes (EDM and fatigue pre-cracking) introduced in the three mock-ups. Figure 19 shows FP1 and FP2 mockups during their preparation (after EDM machining of the notch). 
Table 7: Geometry of mock-ups FP1, FP2 and FP3 (ferritic steel 15NiCuMoNb5)

\begin{tabular}{|c|c|c|c|}
\hline & FP1 & FP2 & FP3 \\
\hline Фinner $(\mathrm{mm})$ & 318 & 318 & 318 \\
\hline Фouter $(\mathrm{mm})$ & 378 & 378 & 378 \\
\hline Thickness $\mathrm{t}(\mathrm{mm})$ & 30 & 30 & 30 \\
\hline Crack depth a/t & - & 0.5 & 0.5 \\
\hline Crack angle $\varphi\left({ }^{\circ}\right)$ & 30 & 30 & 30 \\
\hline Crack shape & TWC & Inner surface crack & Outer surface crack \\
\hline
\end{tabular}
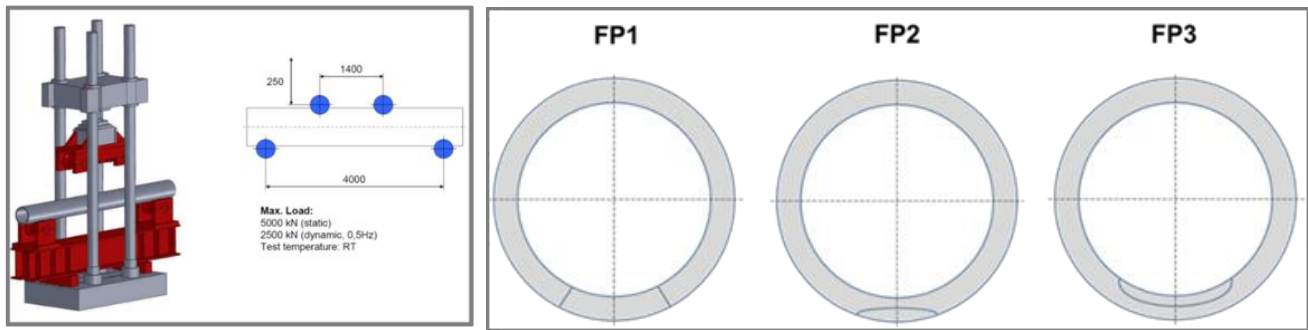

Figure 18. EDF test facility for testing mock-ups and initial flaw shapes of mock-ups
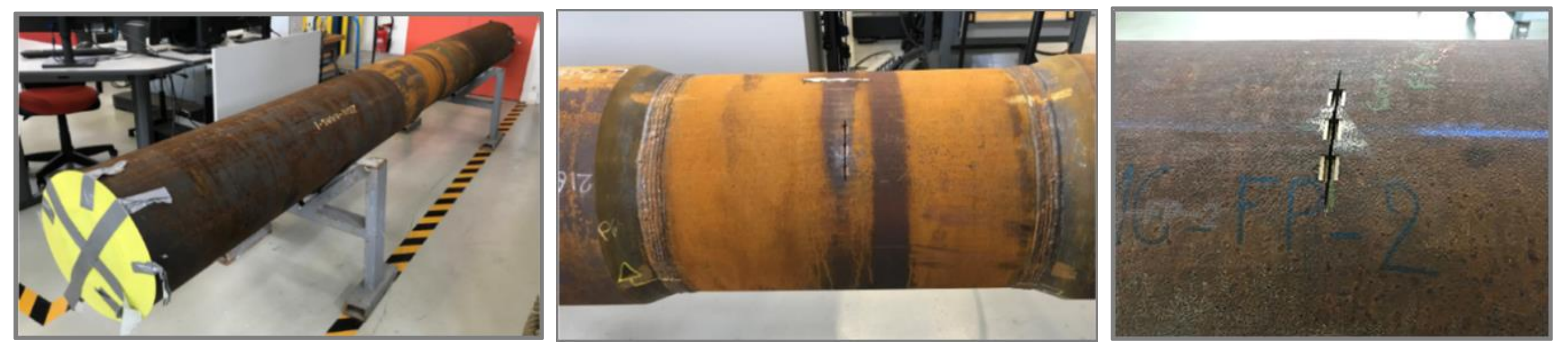

Figure 19. Preparation of mock-ups FP1 and FP2

FP1 test has been made on May 2019 with full success (Figure 20) leading to a significant ductile crack growth at each edge of the initial crack (Figures 20, 21 and 22). The fractographic examination of the fracture surfaces is now in progress. The next tests are now planned during fall 2019 (FP2) and fall 2020 (FP3).
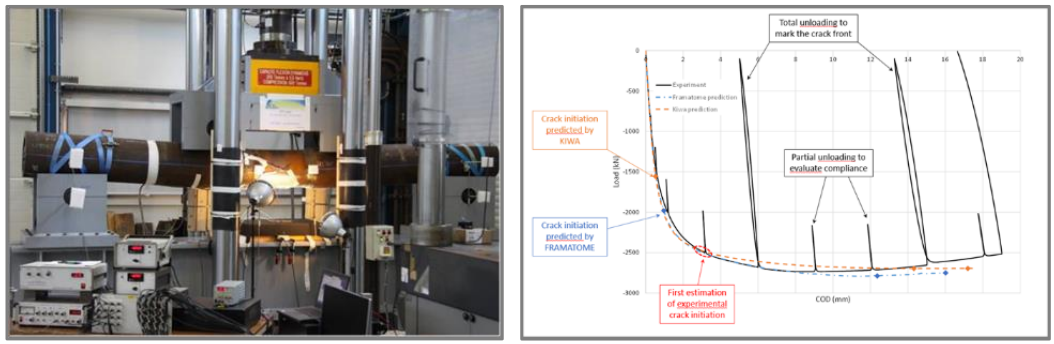

Figure 20. Ductile tearing test of FP1 mock-up with loading path (Load vs COD)
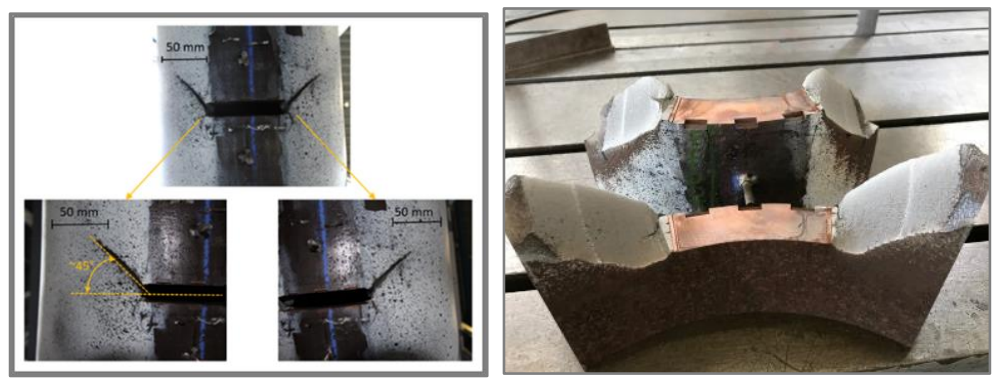

Figure 21. View of the mock-up after the test with large crack growth on each edge of the initial crack 

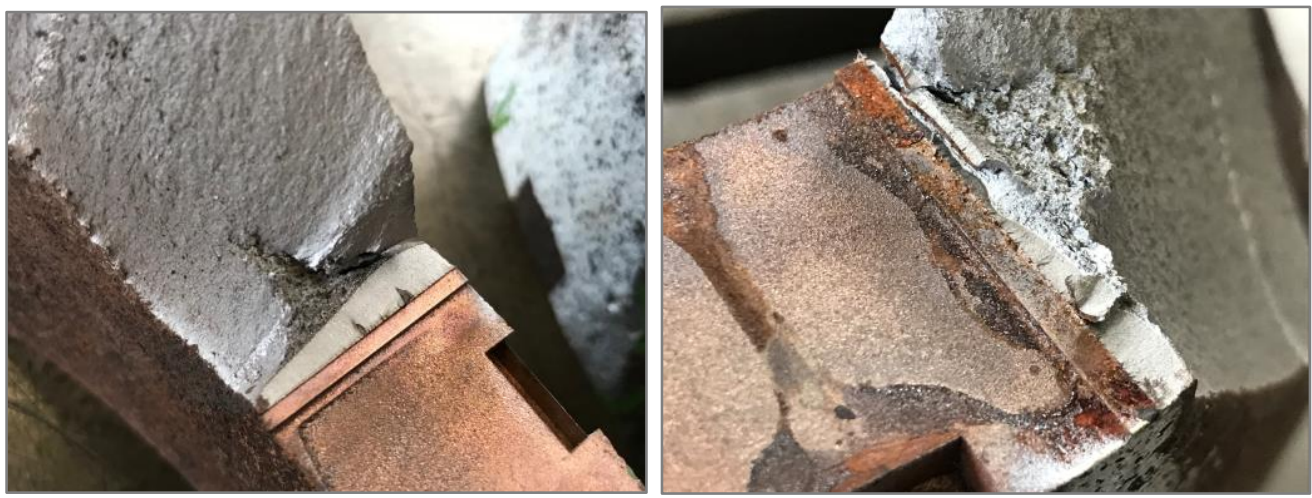

Figure 22. Preliminary observations of fracture surfaces after FP1 test

\section{CONCLUSIONS}

Within the framework of European project ATLAS+, the transferability of ductile properties from small scale specimens to large scale components is studied on the basis of experimental work and numerical simulations conducted on a ferritic material $15 \mathrm{NiCuMoNb} 5$ provided by Framatome $\mathrm{GmbH}$, representative of a German PWR secondary feedwater line.

A large experimental programme of characterization of this material has been conducted and most of the data are now available. The ductile tearing tests conducted at room temperature on CTJ and SENT specimens shows in particular a clear effect of specimen geometry (CT versus SENT) on the ductile behaviour, with a higher ductile tearing resistance observed on SENT specimens.

In addition to this work, three large scale experiments on cracked pipes are planned at room temperature on the EDF test facility. A first ductile test (FP1 test) has been made with full success in May 2019 on a mockup containing a through wall crack. A significant ductile crack growth has been obtained during the test without catastrophic failure of the pipe.

Two other tests are planned by EDF in 2019 (FP2 mock-up) and 2020 (FP3 mock-up) on pipes containing a $1 / 2$ elliptical surface crack located on the outer surface (FP2) or on the inner surface (FP3).

In parallel, the numerical analyses of the large scale tests is in progress by some of the partners of the ATLAS+ project.

\section{ACKNOWLEDGMENTS}

The project ATLAS+ (Advanced Structural Integrity Assessment Tools for Safe Long Term Operation) has received funding from the Euratom research and training programme 2014-2018 under the grant agreement No.: 754589. The project is jointly funded by the EU and individual partners. The authors thank the EU and all the ATLAS+ contributors for their support and contributions.

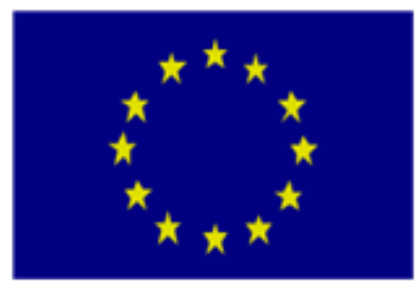

Special thanks to partners directly involved on the characterization of the ferritic steel:

- $\quad$ K. Wallin, S. Lindqvist, S. Marie, E. Keim, T. Nicak, J. Besson, T. Morgeneyer, T. Bolinder, M. Serrano, S. Szabolcs, L. Tatar, M. Bourgeois 


\section{REFERENCES}

[1] Wallin, K., et al, 2018, "Advanced structural integrity assessment tools for safe long term operation (ATLAS+)" Proceedings of ASME 2018 PV\&P Conference, paper PVP2018-84554

[2] Moinereau, D., et al, 2019, 'Experimental support to European project ATLAS+', Proceedings of SMIRT-25 Conference

[3] Dahl, A., Nicak, T., et al., "ATLAS+: Design of large scale fracture mechanics tests on a ferritic pipe" Proceedings of ASME 2018 PV\&P Conference, paper PVP2018-84628

[4] Nicak, T., et al., "Ductile tearing simulations to support design of large scale tests on ferritic pipes to be performed within the European project ATLAS+" Proceedings of ASME 2019 PV\&P Conference, paper PVP2019-93569

[5] Dahl, A., et al., "European project ATLAS+: Small and large scale ductile tearing experiments on ferritic steel WB36 to study transferability of material ductile properties" Proceedings of ASME 2019 PV\&P Conference, paper PVP2019-93070

[6] Moinereau, D., et al, "STYLE project: a large scale ductile tearing experiment on a cladded ferritic pipe”, Proceedings of ASME 2014 PV\&P Conference, paper PVP2014-28077 